\title{
Pathogenicity of Root-knot Nematode (Meloidogyne incognita) on Ivy Gourd (Coccinia indica L.)
}

\author{
Bidisha Sonowal*, Bornali Mahanta and Aprajita Borah
}

Department of Nematology, Assam Agricultural University, Jorhat, Assam- 785013, India

*Corresponding author

\begin{tabular}{|l|}
\hline Ke y w o r d s \\
$\begin{array}{l}\text { Meloidogyne } \\
\text { incognita, Ivy } \\
\text { gourd, } \\
\text { pathogenicity }\end{array}$ \\
\hline Article Info \\
$\begin{array}{l}\text { Accepted: } \\
\text { 05 April } 2020 \\
\text { Available Online: } \\
\text { 10 May } 2020\end{array}$ \\
\hline
\end{tabular}

A B S T R A C T

An experiment was carried out in the net house of department of Nematology, Assam Agricultural University, Jorhat during rabi season 2017 to study the pathogenicity of Meloidogyne incognita on Coccinia indica. For that local variety of Ivy gourd cuttings were planted in $1 \mathrm{~kg}$ capacity pot filled with sterilized soil. One-month old cuttings were inoculated with second stage juvenile of $M$. incognita in a logarithmic series of check, associated check, 10, 100, 1000, 10,000 juveniles $\left(\mathrm{J}_{2}\right)$ per pot. The plants were watered regularly. After 45 days of incubation it was observed that at highest inoculum level plants were very much stunted, chlorotic and with very few branches. Further, it was observed that at the highest inoculum level, root systems were very much reduced with the galls which were bigger in size and mostly coalescent in the roots. The treatment with no nematode (Check and associated check) was free from galls and eggmasses. The observations on the plant growth parameters like plant height, shoot and root weight (fresh and dry) were decreased progressively from initial inoculum level of 100 to highest inoculum level of $10,000 \mathrm{~J}_{2}$ per pot but the nematode multiplications like number of galls per root, eggmasses per root and final nematode population in soil were increased gradually with increase in inoculum level from 10 to $1000 \mathrm{~J}_{2}$ per pot, but it declined at $10,000 \mathrm{~J}_{2}$ inoculum level per pot. Further, it was found that there was no significant difference in plant growth parameters like plant height, shoot and root weight (fresh and dry) and nematode multiplications like number of galls per root, eggmasses per root and final nematode population in soil among the treatments with no nematode i.e Check and associated Check. Moreover, it was observed that there was no significant difference for galls per root, eggmasses per root and final nematode population in soil in between the treatments with 10 and $10,000 \mathrm{~J}_{2}$ per pot.

\section{Introduction}

Ivy gourd, (Coccinia indica L.) is a tropical perennial plant and belongs to the family, Cucurbitaceae. Ivy gourd is also known as baby watermelon, little gourd and popularly known as Tondil/Kundru in India. It is known as 'Kunduli" in Assam. In India, it is widely grown in Tamil Nadu, Assam, West Bengal,
Karnataka, Maharashtra, Bihar, Andhra Pradesh and Gujarat. The Cucurbitaceae family ranks among the highest of plant families for number and percentage of species used as human food. Cucurbits share about $5.6 \%$ of the total vegetable production of India and according to FAO estimate, cucurbits were cultivated on about 4,290,000 ha with the productivity of $10.52 \mathrm{t} / \mathrm{ha}$. 
Ivy gourd is mostly termed as poor man's vegetable (Singh and Singh, 2014). It is a good source of Vitamin A, Beta-carotene, iron, fiber and a good source of protein. Yield of $C$. indica affected due to pest and disease. Among them, root knot nematodes Meloidogyne incognita produces galls on the root and known as root knot disease due to amalgamation of a number of galls. In general, $M$. incognita produces egg masses on galls and it contains more that 250-500 eggs. Such reproductions are governed by many factors like susceptible host, nematode inoculum density and environmental conditions. Our main aim is to reduce the inoculum density of pathogen at below economic injury level. So, it is important to conduct a study on the inoculum density of pathogen against a susceptible host under controlled condition and it helps in formulating the integrated management of that particular pathogen. Keeping this in view an experiment was carried out on pathogenicity of $M$. incognita on $C$. indica

\section{Materials and Methods}

The experiment was carried out in the net house of Department of Nematology, Assam Agricultural University, Jorhat during rabi season 2017 to study the pathogenicity of $M$. incognita on Ivy gourd. Required quantities of earthen pots were collected, filled with $1 \mathrm{~kg}$ of autoclaved soil and labeled according to the allotted treatments and replications. Local variety of Ivy gourd cuttings were planted in $1 \mathrm{~kg}$ capacity pot filled with sterilized soil. The pots were arranged in completely randomized design (CRD) with 5 replications for each treatment. One-month old cuttings were inoculated with second stage juvenile of $M$. incognita in a logarithmic series of check, associated check, 10, 100, 1000, 10,000 juveniles $\left(\mathrm{J}_{2}\right)$ per pot. The plants were watered regularly. Observations on different plant parameters were taken after 45 days of inoculation. Plant heights were recorded before uprooting the plants. Number of galls and egg masses per root system were recorded. Similarly, fresh weight of shoot and roots were taken. For recording dry weight, the plants along with their root systems were packed in a paper bags and kept in an oven at $60^{\circ} \mathrm{C}$ till constant weight of dried plant materials were obtained. The nematode population in the pot soil was determined by washing 200cc of homogenously mixed pot soil by Cobb's Modified sieving and decanting technique (Christie and Perry, 1951). Statistical analysis was performed by using SAS 1.0 software.

\section{Results and Discussion}

The data on pathogenicity of rootknotnematode, $M$. incognita on growth and development of Ivy gourd were presented in Table 1 and 2, Figures 1, 2and 3. After 45 days of incubation it was observed that there was a progressive decrease in all plant growth parameters of Ivy gourd with the increasing inoculum level of $M$ incognita from 10 to $10,000\left(\mathrm{~J}_{2}\right)$ second stage juveniles per pot containing $1 \mathrm{~kg}$ of sterilized soil. At the highest inoculum level plants were very much stunted, chlorotic and with very few branches. It was further observed that at the highest inoculum level, root systems were very much reduced with the galls which were bigger in size and mostly coalescent in the roots. The treatment with no nematode (Check and associated check) was free from galls and eggmasses. The observations on the plant growth parameters like plant height, shoot and root weight (fresh and dry) were decreased progressively from initial inoculum level of 100 to highest inoculum level of $10,000 \mathrm{~J}_{2}$ per pot. However, the highest reduction i.e 13.00 percent of plant growth parameters like plant height shoot and root weight (fresh and dry) was observed in inoculum level of $10,000 \mathrm{~J}_{2}$ per pot. 
Further, it was found that there was no significant difference in plant height, plant height, shoot and root weight (fresh and dry) among the treatments with no nematode (Check and associated Check) and $10 \mathrm{~J}_{2}$ per pot but the treatments having 100, 1000 and $10,000 \mathrm{~J} 2$ per pot differed significantly from each other in plant height, plant height, shoot and root weight (fresh and dry), respectively. Similarly, in respect of nematode multiplications, it was observed that the number of galls per root, eggmasses per root and final nematode population in soil were increased gradually with increase in inoculum level from 10 to $1000 \mathrm{~J}_{2}$ per pot, but it declined at 10,000 inoculum level per pot.

The maximum number of galls per root, eggmasses per root and final nematode population in soil were recorded in the inoculum level $1000 \mathrm{~J}_{2}$ per pot while the minimum galls per root, eggmasses per root and final nematode population in soil were recorded in the treatment with 10,000 and $100 J_{2}$ per pot. Further, it was observed that there was no significant difference for galls per root, eggmasses per root and final nematode population in soil in between the treatments with 10 and $10,000 \mathrm{~J}_{2}$ per pot but these treatments differed significantly from the treatments with 100 and $1000 \mathrm{~J}_{2}$ per pot, respectively.

\section{Discussion}

The results obtained in the study of pathogenicity of root-knot nematode $M$. incognita on Ivy gourd indicated that plants became stunted with the increase of inoculum level of nematode population. This finding is in agreement with the findings obtained by Sable and Darekar (1985) on bitter gourd, Dhankar et al., (1986) on watermelon, Similar findings had also been recorded by Savitri (2006) on Gherkin (small variety of cucumber) and Ash gourd, Singh (2011) on bottle gourd.
Further, it was observed that there was a significant reduction in plant height of Ivy gourd at and above 100 nematodes per pot. Similar results were obtained by Bharali (1996) on cucumber, Savitri (2006) on Ash gourd. The growth parameters of the crop were severely affected with increasing inoculum levels of the nematode which might be due to the destruction of the root system which ultimately affected the nutrient and water uptake. There was a corresponding reduction in fresh and dry weight of shoot of the plants with increase in level of inoculum from 10 to 10,000 nematodes per pot. Similar results were reported by Gupta et al., (1999) on bitter gourd in case of M.javanica, Mahapatra et al., (1999) on pointed gourd, Singh (2011) on bottle gourd. The results further revealed that there was a progressive decrease in root weight (fresh and dry) as the inoculum level of Meloidogyne incognita increased. This finding is in conformity with that of Bharali (1996) who reported significant reduction in fresh and dry root weight on cucumber, Mahapatra et al., (1999) on pointed gourd, Savitri (2006) on Ash gourd.

Further, it was observed that the plants at highest inoculum level $(10,000$ nematodes per pot) had a poor stand, root system was very much reduced and feeder roots were completely absent. Similar results were reported by Dhankar et al., (1986) on watermelon, Bharali (1996) on cucumber. There was a progressive increase in number of galls and eggmasses with increase in inoculum level from 10 to 1000 and declined at 10,000 inoculum level per pot. Similar findings were obtained by Paruthi and Gupta (1985) on bottle gourd, Dhankar et al., (1986) on watermelon, Bharali (1996) on cucumber. There was a progressive increase in nematode population in pot soil with the increase in inoculum level from 10 to 10,000 nematodes per pot. 
Table.1 Effect of different inoculum levels of Meloidogyne incognita on plant growth parameters of Ivy gourd (Mean of 5 replications)

\begin{tabular}{|c|c|c|c|c|c|}
\hline $\begin{array}{c}\text { Inoculum level } \\
\left(\mathbf{J}_{2} / \mathrm{kg} \text { soil }\right)\end{array}$ & $\begin{array}{l}\text { Plant } \\
\text { height } \\
(\mathrm{cm})\end{array}$ & $\begin{array}{c}\text { Fresh } \\
\text { weight of } \\
\text { shoot (g) }\end{array}$ & $\begin{array}{c}\text { Dry } \\
\text { weight of } \\
\text { shoot }(g)\end{array}$ & $\begin{array}{c}\text { Fresh } \\
\text { weight of } \\
\text { root }(\mathrm{g})\end{array}$ & $\begin{array}{c}\text { Dry } \\
\text { weight of } \\
\text { root (g) }\end{array}$ \\
\hline $\mathrm{T}_{1}$ :Check & $89.18^{\mathrm{a}}$ & $20.02^{\mathrm{a}}$ & $3.44^{\mathrm{a}}$ & $11.04^{\mathrm{a}}$ & $2.38^{\mathrm{a}}$ \\
\hline $\mathbf{T}_{2}$ :Associated check & $88.78^{\mathrm{a}}$ & $19.56^{\mathrm{a}}$ & $3.10^{\mathrm{a}}$ & $10.28^{\mathrm{a}}$ & $2.20^{\mathrm{a}}$ \\
\hline$T_{3}: 10$ & $85.98^{\mathrm{a}}$ & $15.16^{\mathrm{b}}$ & $2.84^{\mathrm{a}}$ & $10.16^{\mathrm{a}}$ & $1.56^{\mathrm{b}}$ \\
\hline$T_{4}: 100$ & $57.98^{b}$ & $15.06^{\mathrm{b}}$ & $2.06^{b}$ & $8.36^{b}$ & $1.52^{b}$ \\
\hline$T_{5}: 1000$ & $42.50^{c}$ & $10.08^{\mathrm{c}}$ & $1.60^{c}$ & $6.72^{c}$ & $1.09^{c}$ \\
\hline$T_{6}: 10,000$ & $22.36^{d}$ & $7.18^{\mathrm{d}}$ & $1.08^{\mathrm{d}}$ & $4.92^{d}$ & $0.77^{d}$ \\
\hline S.Ed. $( \pm)$ & 1.61 & 1.11 & 0.20 & 0.60 & 0.13 \\
\hline $\mathrm{CD}_{0.05}$ & 3.33 & 2.29 & 0.41 & 1.25 & 0.28 \\
\hline
\end{tabular}

*Mean followed by the same letter in the superscript(s) are statistically at par

Table.2 Effect of different inoculum levels of Meloidogyne incognita on number of galls, eggmasses and nematode population on Ivy gourd. (Mean of 5 replications)

\begin{tabular}{|c|c|c|c|c|}
\hline $\begin{array}{c}\text { Inoculum level } \\
\left(\mathbf{J}_{2} / \mathrm{kg} \text { soil }\right)\end{array}$ & $\begin{array}{c}\text { No.of } \\
\text { galls/ } \\
\text { root } \\
\text { system }\end{array}$ & $\begin{array}{c}\text { No.ofeggm } \\
\text { asses / root } \\
\text { system }\end{array}$ & $\begin{array}{l}\text { Final nematode } \\
\text { population }(200 \\
\text { cc of soil) }\end{array}$ & $\begin{array}{l}\text { Reproducti } \\
\text { ve rate }(\%)\end{array}$ \\
\hline $\mathrm{T}_{1}$ :Check & $\begin{array}{c}0.00 \\
(0.70)^{\mathrm{d}}\end{array}$ & $\begin{array}{c}0.00 \\
(0.70)^{d}\end{array}$ & $\begin{array}{c}0.00 \\
(0.70)^{d}\end{array}$ & 0.00 \\
\hline $\mathbf{T}_{2}$ :Associated check & $\begin{array}{c}0.00 \\
(0.70)^{\mathrm{d}}\end{array}$ & $\begin{array}{c}0.00 \\
(0.70)^{d}\end{array}$ & $\begin{array}{c}0.00 \\
(0.70)^{d}\end{array}$ & 0.00 \\
\hline$T_{3}: 10$ & $\begin{array}{c}34.00 \\
(5.86)^{c}\end{array}$ & $\begin{array}{c}20.20 \\
(4.53)^{c}\end{array}$ & $\begin{array}{c}333.96 \\
(18.14)^{\mathrm{c}}\end{array}$ & 33.39 \\
\hline$T_{4}: 100$ & $\begin{array}{c}112.4 \\
(10.61)^{b}\end{array}$ & $\begin{array}{l}35.40 \\
(5.97)^{b}\end{array}$ & $\begin{array}{l}1175.94 \\
(34.18)^{b}\end{array}$ & 11.75 \\
\hline$T_{5}: 1000$ & $\begin{array}{c}158.2 \\
(12.58)^{\mathrm{a}}\end{array}$ & $\begin{array}{c}68.60 \\
(8.30)^{\mathrm{a}}\end{array}$ & $\begin{array}{l}2832.00 \\
(52.97)^{\mathrm{a}}\end{array}$ & 2.83 \\
\hline$T_{6}: 10,000$ & $\begin{array}{l}31.60 \\
(5.62)^{c}\end{array}$ & $\begin{array}{c}17.60 \\
(4.24)^{\mathrm{c}}\end{array}$ & $\begin{array}{l}3096.00 \\
(55.52)^{\mathrm{a}}\end{array}$ & 0.30 \\
\hline S.Ed.( $( \pm)$ & 0.14 & 0.16 & 2.01 & \\
\hline $\mathrm{CD}_{0.05}$ & 0.30 & 0.34 & 4.16 & \\
\hline
\end{tabular}

Values of number of galls, eggmasses and final nematode population within parentheses are square root $(\sqrt{\mathrm{x}+0.5})$ transformed data. Mean followed by the same letter in the superscript(s) are statistically at par. 


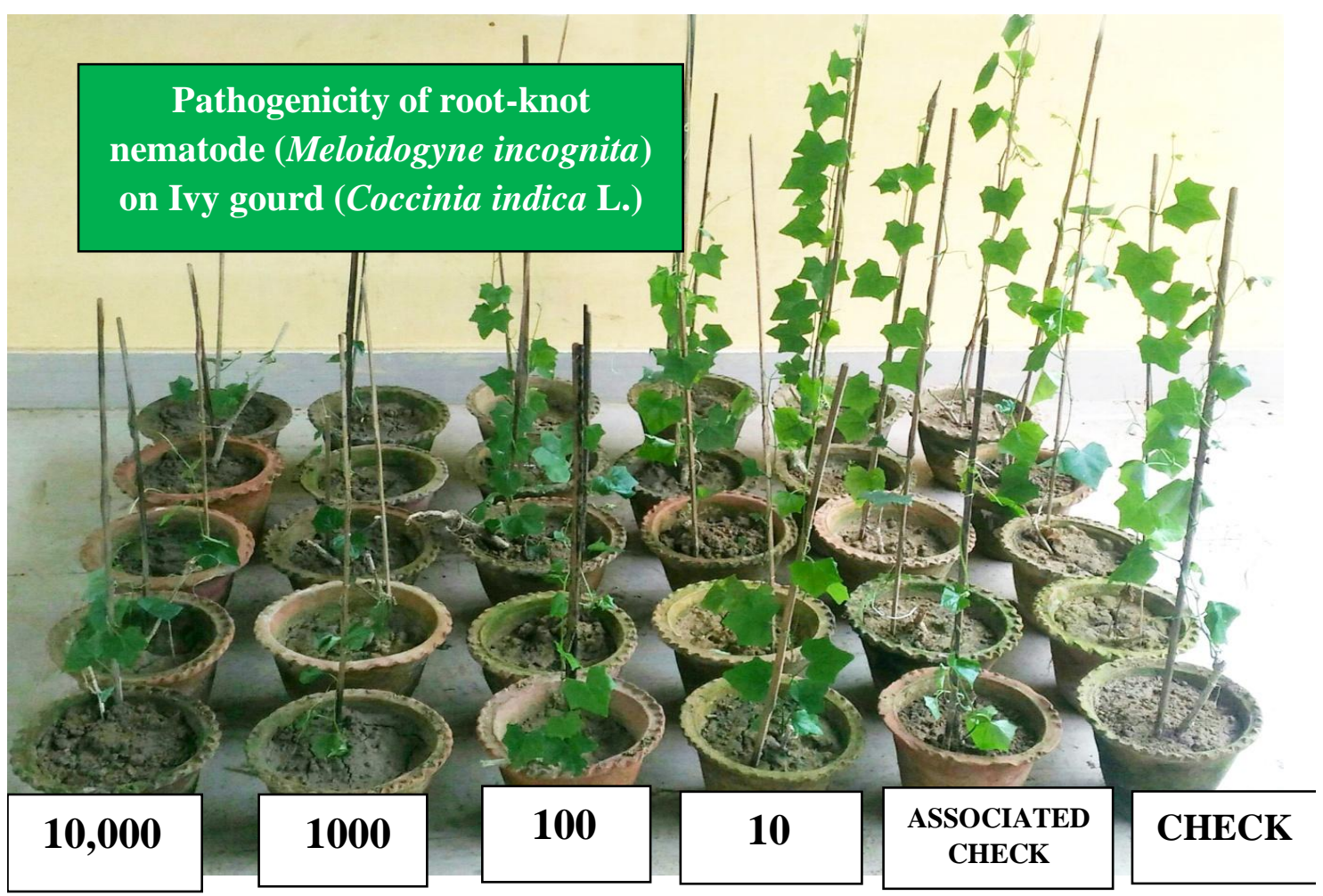

Fig.1 General View of the pot-experiment on Ivy gourd

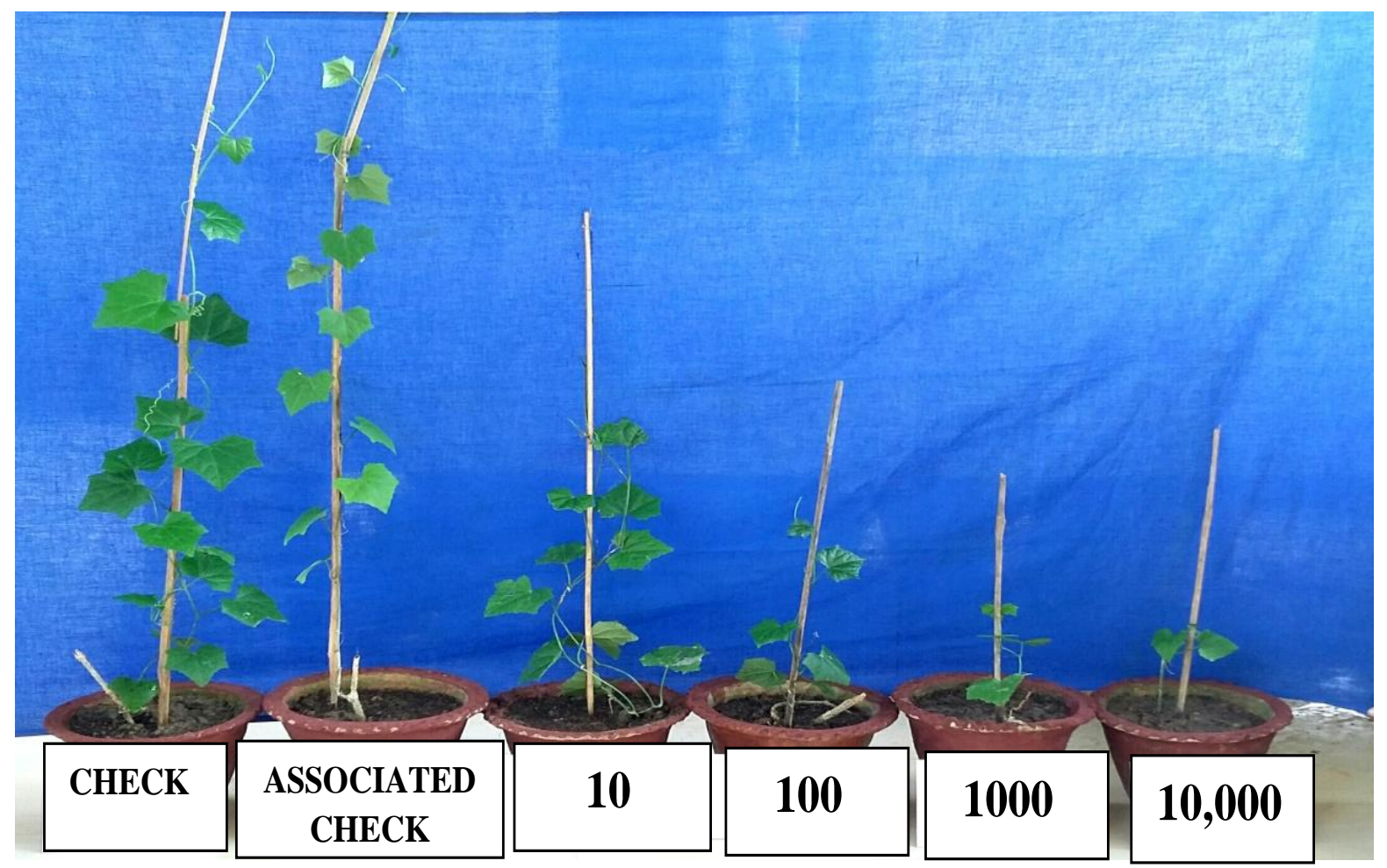

Fig.2 Growth of Ivy gourd under different inoculum levels of Meloidogyne incognita 

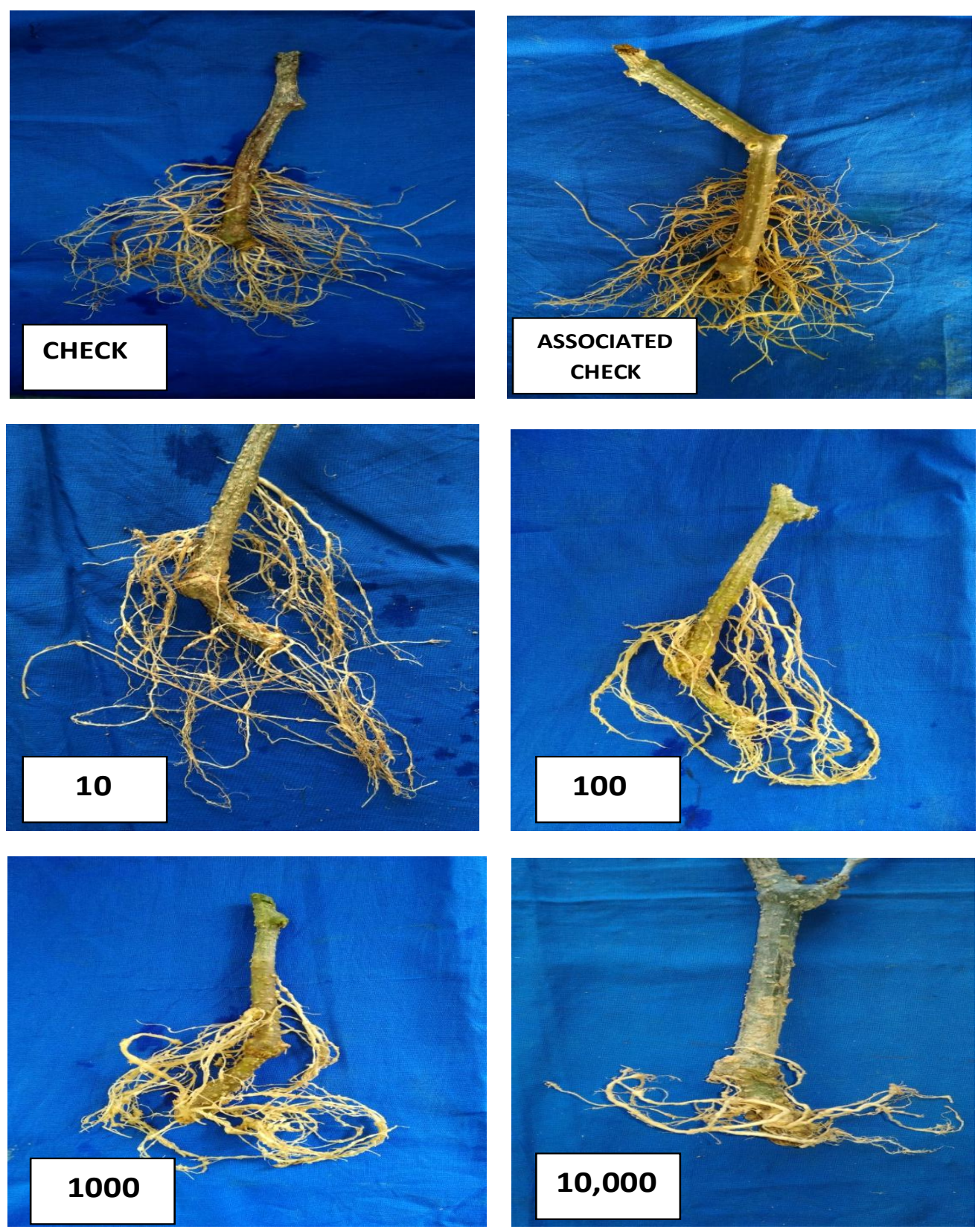

Fig.3 Effect of different inoculum level of Meloidogyne incognita on root growth of Ivy gourd

A gradual increase in nematode population with increase in inoculum level was reported by Venkatesan (2009) on bitter gourd, Singh (2011) on bottle gourd. The gradual increase in nematode population results in gradual decrease in reproductive rates. The maximum (33.39) and minimum (0.30) reproductive rate of nematodes were recorded in the lowest inoculum level (10) and highest inoculum level (10,000) per pot respectively. Highest multiplication rate was recorded at lowest inoculum level by Verma and Anwar (1995) on pointed gourd, Singh (2011) on bottle gourd. As suggested by Triantaphyllu and Hirschmann (1960) variation in growth rate of $M$. incognita is caused by competition for food and overcrowding and development is retarded where numerous larvae enter the same root system. 


\section{References}

Bharali, A. (1996). Pathogenicity and management of Meloidogyne incognita on cucumber. M.Sc. (Agri.) Thesis on Nematology, submitted to Assam Agricultural University, Jorhat.

Christie, J.R. and Perry, V.G. (1951). Removing nematodes from soil. Proc. Helminth Soc. Wash. 18: 106-108.

Dhankar, R. K.S., Sharma C., Sarna, N.T. and Trivedi, P.C. (1986). Pathogenicity of Meloidogyne incognita on watermelon (Citrullus vulgarisScharad). Indian J. of Nematol. 16 (2): 274.

Gupta, D.C.,Paruthi, I.J. and Jain, R.K. (1999). Effect of initial inoculum levels of Meloidogyne spp. on some cucurbitaceous crops. Indian $J$. Nematol. 25(2): 194-199.

Mahapatra, S.N., Swain, P.K. and Behera, B. (1999). Pathogenicity and management of root-knot nematode (Meloidogyne incognita) in pointed gourd (Trichosan thesdioica). Indian J. Agric. Sci., 69: 275-277.

Paruthi, I.J. and Gupta, D.C. (1985). Pathogenicity of root-knot nematode, Meloidogyne javanica on bottle gourd (Lagenaria siceraria) using two methods of inoculation. Indian $J$. Nematol. 15(1): 52-54.

Sable, A.N. and Darekar, K.S. (1985).
Pathogenicity of Meloidogyne incognita to bitter-gourd, Momordica charantia L. Int. Nematol. Net. Newsl. 2(4): 13-14.

Savitri, D. (2006). Studies on root-knot nematode, Meloidogyne spp. on cucurbitaceous vegetables. M.Sc. (Agri.) Thesis on Nematology, submitted to Acharya N.G. Ranga Agricultural University, Hyderabad.

Singh, P.K. and Singh, M. (2014). Everyone's vegetable: Ivy gourd Kashi Bharpoor to enrich vegetable basket. Indian Hort.59(2): 6-7.

Singh, T. (2011). Investigations on root-knot nematodes (Meloidogyne spp.) on bottle gourd. M.Sc. (Agri.) Thesis on Nematology, submitted to Anand Agricultural University, Anand.

Triantaphyllu, A.C. and Hirschmann, H. (1960). Post-infection development of Meloidogyne incognita Chitwood, 1949. Ann. Inst. Phytopath. Benaki. N.S. 3: 111.

Venkatesan, M. (2009). Investigations on root-knot nematodes (Meloidogyne spp.) in bitter gourd. M.Sc. (Agri.) Thesis on Nematology, submitted to Anand Agricultural University, Anand.

Verma, A.C. and Anwar, A. (1995). Pathogenicity of Meloidogyne incognita in pointed gourd (Trichosan thesdioica). Indian J. Mycol. Pl. Pathol. 25: 70.

\section{How to cite this article:}

Bidisha Sonowal, Bornali Mahanta and Aprajita Borah. 2020. Pathogenicity of Root-knot Nematode (Meloidogyne incognita) on Ivy Gourd (Coccinia indica L.). Int.J.Curr.Microbiol.App.Sci. 9(05): 929-935. doi: https://doi.org/10.20546/ijcmas.2020.905.102 